\title{
Synthesis Model on the Implementation of Public Policy in National Community Empowerment Program in Makassar and Parepare, South Sulawesi
}

\author{
Suratman, Muh. Akmal Ibrahim \& Ali Fauzy Ely
}

\begin{abstract}
PNPM Mandiri Urban is a government program that substantially seeks poverty alleviation, but it has not been effective yet. This research's aims (in the third year of the implementation of synthesis or integrated model according to Winter) are: inter-organizational behavior, street level bureaucratic behavior, and target group behavior. Design used in this research is qualitative design with case study strategy. The data is collected through observation, thorough interview, FGD, and documentation. The output is in the form of scientific journal or international journal and textbook. The data analysis is conducted using case descriptive analysis and its setting, qualitative experiment, or analysis based on theoretical analysis. The research result and discussion show that both organization and the street level bureaucratic behavior follow the guidance from the head, except for target group, especially a very good response from the community to PNPM Mandiri Urban program. Even, the community gets involved, and no one of them disagreeing or obstructing the program implementation, either in Parepare or Makassar.
\end{abstract}

Keywords: Synthesis Model of the Implementation of PNPM Mandiri Urban Policy

\section{Introduction}

National Community Empowerment Program (PNPM) Mandiri Urban that has been implemented from 2007 is renamed into Quality Improvement Program for Urban Settlement (P2KP). Based on National Socio-Economic Survey on March 2017, the number of poor people in South Sulawesi in March 2017 is 813.07 thousand people or $9.38 \%$ of total population. The number of poor citizen in South Sulawesi fluctuatesevery year.

Research result of the first step using top-down model by Van Meter and Van Horn (Suratman et al 2016) shows that the performance is not in line with the implementation of PNPM Mandiri Urban policy. On the contrary, bottom-up methodis more suitable for the implementation of the policy with the research result of the second step about bottom-up model as stated more by Suratman et al (2017). Environmental factors are only in the form of caring and working together, helping each other, and the level of community participation. Likewise, the third generation of the implementation model is synthesis or integrated model, of which the research result is stated by Soren C. Winter (2003) indicating that the success of implementation is determined from formulation to evaluation process, which automatically means that there is relationship between politics and administration process.

Referring to synthesis or integrated model, it is seen clearly that the implementation of the policy is really influenced by the policy design that is basically determined by the formulation of the policy itself. Another influential factor is socio-economic condition of the community. A policy will be influenced by the environment where the policy is implemented. Meanwhile, according to Winter, the implementation itself is related to the organization behavior and the leading bureaucratic behavior as the policy implementers who communicate with the target group of the policy. Therefore, this research title is "Implementation Model of Integrated Policy in the National Urban Community Empowerment Program in Makassar and Parepare, South Sulawesi” (Synthesis Model of Policy Implementation).

\section{Literary Review}

One of the public administration paradigmsis public policy paradigm, in both the context of inner problem ("inner system") and interaction with its environment ("outer system"), facing several challenges of change that often contains uncertainty (Mustopadijaja, 1985). 
Public policy is "Public policy is whatever governments choose todoornottodo"(Thomas R. Dye,1972).This definition is in line with William N. Dunn (1999) stating that public policy is a series of government action (including decision to not to choose) in order to respond to challenges related to the society. Selfexecuting decision is rarely found. Implementation is defined as the implementation of a policy decision(Mazmanian and Sabatier, 1983).Policy implementation is basically an action to reach the goal of a policy (Nugroho, 2003).

In the development of policy implementation study, Pressman and Wildavsky (1973) are influential figures. The policy makers consider that once they make a decision, the implementers (government departments) will be easy to implement it. However, Hawlett and Rames (2003) explains the importance of this study after they show the failure of the implementers in reaching the goals of job creation program in Oakland, California, that has been determined by the policy makers. This study brings to debate about conditions required for successful policy implementation. It becomes the essence of the top-down model in policy implementation.

This idea of implementation model of top-down rational system or ideal type is then developed by Dunsire (1978) proposing model that is questioning what the ideal implementation model is look like. This idea is certainly in line with Weber construction about ideal bureaucracy model type. The organizational structure of bureaucracy is made to operate as precisely as possible through authority pattern such as job responsibility and the right to provide proper compliance (Morgan, 1986). Thus, Anderson (1979) saysthat very important aspect of public policy implementation is compliance.

The occurrence of bottom-up model is a critic for top-down model (Winter in Peter in Pierre, 2003). In more extreme critics, Goggin et al (1990) considers top-down model as the first generation research with characteristics of theoretical, case-specific, and non-cumulative. Therefore, it cannot be made as the base of more complex phenomenon. According to bottom-up model, implementation process involves policy makers of those related to the policy implementation. Policy implementation, according to Smith (cited from Putra, 2003) is not linear and mechanistic, but it opens up opportunityfor transaction through negotiation, or bargaining to obtain compromise towards the policy implementation in target group dimension.

Top-down and bottom-up model in the implementation of public policy, according to Lewis and Plynn (cited from Parson, 1997) tend to too simplify implementation complexity. Thus, the most proper alternative in any situations, according to Sabatier and Mazmanian (1997) "is to synthesize the best features of the two approaches". The implementation of this synthesis model in many literature of public policy implementation is usually called integrative implementation model (Soren C. Winter, 2003; Goggin et.al, 1990), and Groggin et al call it as the third generation of public policy implementation. This synthesis model is a combination of top-down and bottomup models. This model also shows the complementarity between the two models (Sabatier cited by Hawlett and Rames, 2003) because top-down model focuses on the goal achievement of a policy implementation, while bottom-up model highlights in the problem solving of the policy implementation.

General purpose of PNPM that has been determined by General Guidance of PNPM is "To improve poverty and job vacancy for poor people independently." Synthesis model of public policy implementation (Soren C. Winter, 2003) sees clearly that the public implementation is really influenced by the policy design that is basically established and determined by the formulation of the policy itself. Meanwhile, according to Winter, the implementation itself is related to organization behavior, leading bureaucracy behavior as the policy implementers which communicate with the target group behavior of the policy.

\section{Picture 2.1. Research Conceptual Framework}

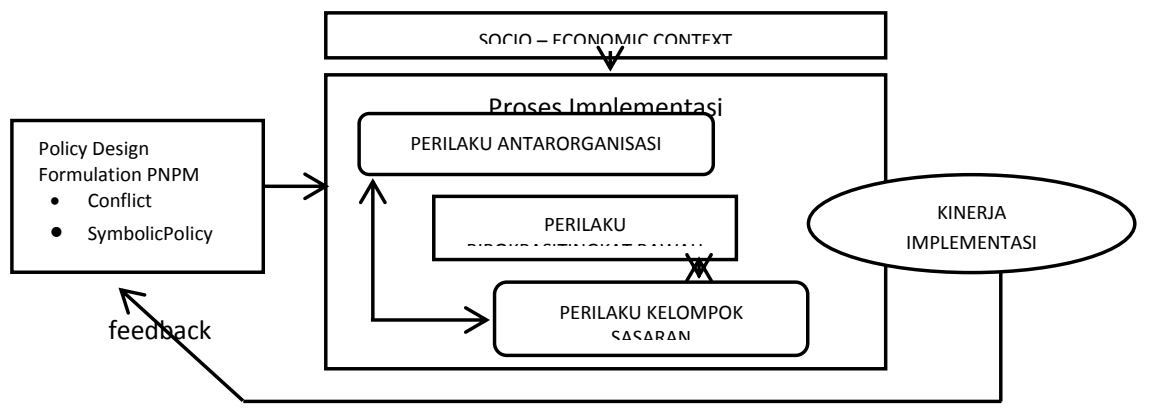

Source: Adapted from Soren C. Winter, 2003 about Synthesis Model of Public Policy Implementation 


\section{Research Method}

This research is conducted in Makassar and Parepare. Makassar is chosen as the research place because it is a capital city of South Sulawesi with high number of poor people. Meanwhile, Parepare is chosen due to its position as one of the cities with low number of poor people in South Sulawesi. This research design is logical structure that connects empirical data to objective studies, so the conclusions based on the fact can be generated (Moleong, 1987, Yin, 2000). This research uses qualitative design with study case strategy. The output is in the form of accredited science journal or international journal and textbook.

Informants of this research are determined using purposive method (Neuman, 1997). The informants are: Development Planning Agency at Sub-National Level (Bappeda) of Makassar and Parepare, Department/SKPD PU of Makassar and Parepare, Social Department/SKPD of Makassar and Parepare, Coordinator and staff of TKPKD of Makassar and Parepare, and some NGOs for poverty in Makassar and Parepare.Techniques used for data collection are observation, thorough interview, FGD, and documentation. Techniques of data processing are thorough interview, observation, and documentation. The analysis can be carried out using both qualitative experimental design and descriptive qualitative analysis (Moleong, 1987, Yin, 2000).

\section{Result and Discussion}

\section{Organizational and Inter-organizational Behavior}

Dimensions of organizational or inter-organizational behavior are inter-organizational commitment and coordination. The implementation of public policy in reaching for optimal result rarely happens in its own group without other organizations as the supporter or implementer. In both Parepare and Makassar, there is Work unit of Coordination Team for Regional Poverty Alleviation (TKPKD). There is also City Coordinator (Kordinator Kota or Korkot) in Parepare, then Person in Charge in District Operation (Penanggung Jawab Operasional Kecamatan or PJOK) in District level, and in Sub-district level. After then, there is Community Self-Help Institution (Lembaga Keswadayaan Masyarakat or LKM) in Parepare or well-known as Community Self-Help Board (Badan Keswadayaan Masyarakat or BKM). For further explanation, data from the interview with informants is reduced, and the conclusion obtained is as follow:

Parepare City. The city is coordinated directly by Mayor or Regent through Bappeda by signing Coordination Team of PNPM Implementation (TKPKD). The regional government is assisted by Committing Officers (Pejabat Pembuat Komitmen or PPK) that is assigned by the Ministry of Public Works based on the proposal by the Mayor/Regent under the supervision of City/District Unit Works in controlling the implementation of assistance activity and BLM fund disbursement. TKPKD of City/District in PNPM Mandiri Urban plays a role to coordinate TKPKD in various poverty alleviation programs. (interview with TKPKD Bappeda dated 30-4-2018). Makassar City. This program is made by the central government, so all elements of SKPD are involved, starting from Bappeda, social department, and Public Works department. The mechanism is the central government decides the bureaucracy structure, funding mechanism and disbursement cycle have been determined by the centre. (Bappeda dated 18-5-2018).

In the implementation and control of activity in City/District Level will be conducted by City Coordinator (Korkot) that is helped by some assistance in accounting management, engineering/infrastructure, data management, and spatial planning. The relationship between Central TKPKD, Provincial TKPKD, and City/District is the Central TKPD is more focused on preparing systems (norms, standard, procedures, and manuals) for poverty alleviation from the central level to regional level. Coordination and synchronization of the arrangement and the implementation of poverty alleviation policy as well as the control of the implementation of poverty alleviation policy based on the regional characteristics and potential and advanced policy determined by regional government for poverty alleviation is carried out by each region.

Commitment of all stakeholders is to answer all challenges of poverty alleviation through reaching for target and achievement of the reduction of the percentage of poor people, minimizing unequal percentage of poor citizens among regions, and overcoming vulnerability to poverty for the community in Parepare. Commitment between stakeholders guards the Municipal Medium-Term Development Plan for strengthening Regional Revenue and Expenditure Budget (Anggaran Pendapatan dan Belanja Daerah or APBD). PNPM Mandiri is a national program, so all stake holders have shared commitment to implement the program. It is conducted by forming a work unit consisting of Bappeda as leading sector, Public Works Department, Community Empowerment Department, and Social Department. 


\section{Street Level Bureaucratic Behavior}

Dimensions of street level bureaucratic behavior is discretion. Discretion is a decision and/or action determined to overcome concrete action facing government regulation. For further explanation, data from the interview with informants is reduced, and the conclusion obtained is as follow:

Parepare City. There is no policy or special decision because it is only an extension of Provincial Work Unit, and Public Works Department - in this case is Directorate General of Human Settlements - is the one which has full authority. In the central government, there is PMU (Project Management Unit) which responsible for the whole activity in implementing the program. After then, accounting administration and human resource will be the responsibility of Work Unit PBL, like us in Parepare that are assigned as PPK. (Interview with Work Unit dated 30-4-2018). Makassar City. There is limited discretion, where PNPM program has owned implementation guidance (juklak) and technique guidance (juknis). Discretion is limited only in the program proposal for poor people, improvement of environmental infrastructure program, home improvement, drainage reparation, paving block, clean water, and sanitation. Therefore, the discretion is only to choose which program is suitable for the society need including in PNPM Mandiri program. Likewise, economic sector adapts to the need of the poor society that will be helped (Interview with Public Works Department dated 21 May 2018).

Work Unit, either in Parepare or Makassar, in terms of making decision or policy, is limited only in proposing program if there is guidance from provincial or center work unit that does not reach the target. For example, we can propose Korkot including its district facilitator team if the report is not on time, or the district facilitator is promoted to be provincial work unit. Additionally, we can delay the district facilitators' salary if there is BKM officer who report them.

\section{Socio-Economic Activity}

Target group behavior does not only affect the policy, but also bureaucracy/lower level apparatus performance. Its dimension covers positive and negative response of the society in supporting or not supporting the policy. For further explanation, data from the interview with informants is reduced, and the conclusion obtained is as follow:

Parepare City. Many people feel the benefits, and even sustainable things like revolving funds that are run by BKM and KSM until now. It means that the society has known the benefits (Interview with Work Unit dated 3004-2018). Makassar City. The result of our assistance in several districts and sub-districts shows that the program helps the people's economy so that they are able to learn to manage their family economy. (Interview with NGO for poverty dated 22-5-2018).

After knowing that this program empowering poor people for the future, let's see people who have ever got PNPM, they must be saying that this program is very good. Moreover, PNPM no longer exist even though it is renamed into Clean City or KOTAKU (Kota Tanpa Kumuh).

\section{Policy Formulation}

\section{Conflict and Type of Conflict}

Definition of a term 'conflict' in its original language, according Webster in Pruitt and Tubin (2004:9) is fight, war, struggle, that is, physical confrontation among several parties, Weingart and Jehn (2009:328-329) identify that two types of conflict in organization are conflict of duty and conflict of relationship. BKM PNPM Mandiri should be the only acknowledged institution available for the community. On the contrary, there are community institutions formed by the government such as LPM and some empowerment activities which are then entered by forming BKM. Pulling between BKM and LPM and other community empowerment program is often questionable.

\section{Symbolic Policy}

Symbolic policy means policy not compelling because it only give small impact on the society. Therefore, PNPM MP aims to help the society in sub-district level in order to make the society independent through Tridaya, covering infrastructure development, economic development in business capital, and social development. Many people feel the benefits of PNPM MP, but it still needs to be followed by economic and social development to make it balance with infrastructure development. 


\section{Conclusion}

1.The dimensions of organizational and inter-organizational behavior are inter-organizational coordination and commitment. The implementation of public policy in reaching for optimal result rarely happens in its own group without other organizations as the supporter and the implementer. In order to make efficient and effective implementation, it is important to have cooperation and coordination with several organizations, or the parts of the organization.

2. The dimension of street level bureaucratic behavior is discretion. The next variable that becomes the main factor of the policy implementation is street level bureaucratic behavior. It is expected to implement program as important decision using more dominant influence beside formal authority (discretion).

3. Target group behavior does not only affect the policy, but also bureaucracy/lower level apparatus performance. Its dimension covers positive and negative response of the society in supporting or not supporting the policy. Target group behavior, especially the society, gives good response towards PNPM Mandiri Urban, and even they are involved and there is no one of them that disagrees or prevent the implementation of PNPM Mandiri in both Parepare and Makassar. Many people feel the benefit as well as other sustainable things like revolving fund that is still conducted by BKM and KSM.

4. Those three behaviors determine public policy implementation that is finally back to the formulation of the policy, either conflict - conflict of duty and conflict of relationship — or symbolic policy, which is a policy not compelling due to its small impact on the society.

\section{Bibliography}

Anderson, J. E. 1979. Public Policy Making. NY: Holt, Rinehart and Winston.

Dunn, N. William, 1999. Pengantar Analisis Kebijakan Publik, edisi kedua, Yogyakarta, Gadjah Mada University Press.

Dunsire, A. 1973. Administration : The Word and the Science, Published in the U.S.A by the Halsted Press, a Division of John Wiley \& Sons, Inc., New York.

Dye, Thomas R. 1972. Understanding Public Policy, Englewood Clifls, NJ: Prentice-Hall.

Goggin, Malcolm L. et.al. 1990. Implementation Theory and Practice, Toward a Third Generation. USA: Scott, Foresman and Company.

Howlett dan Ramesh.1995. Studying Public Policy : Policy Cyecles and Policy Subsystems, Oxford University Press.

Pruitt G. Dean dan Jeffrey Z. Rubbin. 2004. Teori Konflik Sosial, Seri Psikologi Sosial, Cetakan Kelima, Alih Bahasa Helly P. Soetjipto dan Sri Mulyantini, Jakarta, Pustaka Pelajar.

Parsons, Wayne, 2005. Public Policy: An Introdustion to the Theory and Practice of Policy Analysis. Cambridge: Edward Elgar Publishing, Inc.

Peire and Peterson, 2003. Policy Network. In Antje Wiener and Thomas Dies, Europan Integration Thery, Viena Oxford, University Press.

Pressman, Jeffrey and Aaron Wildawsky, 1973. Implementation. California: University of California Press.

Suratman, Akmal, Ali Fauzy. 2016. Model Implementasi Kebjakan Publik Terpadu Dalam Progaram Nasional Pemberdayaan Masyarakat Di Kota Makassar dan Kota ParepareProvinsi Sulawesi Selatan (Model Implementasi Top-Down - Generasi Pertama), Makassar, Hikom Dikti - LP2M Unhas (tahap I)

Suratman, Akmal, Ali Fauzy. 2017. Model Implementasi Kebjakan Publik Terpadu Dalam Progaram Nasional Pemberdayaan Masyarakat Di Kota Makassar dan Kota ParepareProvinsi Sulawesi Selatan (Model Implementasi Bottom- Up- Generasi Kedua), Makassar, Hikom Dikti - LP2M Unhas (tahap II)

Lipsky, M., 1980. Street-Level Bureaucracy: Dilemmas of the Individual in Public Services. Russell Sage Foundation.

Moleong, Lexy J., 1997. Metodologi Penelitian Kualitatif. Edisi Revisi. Cetakan Kedua Puluh Empat. Remaja Rosdakarya. Bandung.

Neuman, W. Laurence, 1997.Social Research Methods, Qualitative and Quantitatif Approaches. $3^{\text {rd }}$ Edition.Allyn and Bacon. USA.

Yin, Robert K., Prof.Dr. 2000. Studi Kasus : Desain dan Metode. Cet. III, Terjemahan M. Djauzi Mudzakir. Jakarta : Raja Grafindo Persada

Smith dalam Putra, Fadillah. 2003. Paradima Kritis Dalam Studi Kebijakan Publik, Pustaka Pelajar, Yogyakarta. 
Mazmanian, Daniel A. Dan Sabiter, Paul A. 1983. Impelementation and Public Policy. Scott, Foresman and Company, New Jersery.

Morgan, G. 1991. Images of Organization, SAGE Publications, Inc, Newbury Park, California.

Mustopadidjaja AR. 1985. Paradigma-Paradigma Pembangunan dan Saling Hubungannya dengan Model, Strategi, dan Kebijakan dalam Penyelenggaraan Pemerintahan dan Pembangunan, Jakarta, LAN-RI.

Neuman, W. Laurence, 1997.Social Research Methods, Qualitative and Quantitatif Approaches. $3^{\text {rd }}$ Edition.Allyn and Bacon. USA.

Nugroho D. Raiant. 2004. Kebijakan Publik. Formulasi, Implementasi dan Evaluasi.. Jakarta, Gramedia.

Van Meter, Donald S. \& Van Horn, Carl E. 1975. The Policy Implementation Process, A Conceptual Framework. Dalam Jurnal Administration and Society. Vol. 6 No. 4 Feb. 1975.

Weingart, L. R., and Jehn, K. A., 2009. Manage Intra-Team Conflict through Collaboration", in Handbook of Principles of Organizational Behavior, edited by Edwin Locke, West Sussex, UK.: John Wiley \& Sons, Ltd., pp. 327-346.

Winter, Soren C. 2003. Implementation Perspectives: Status and Reconsideration. Dalam Handbook of Public Administration. London: Sage Publications Ltd. 